\title{
Rights of Ownership of Minors from the Position of the Russian Law
}

Zamira A. Akhmetyanova ${ }^{1}$, Timofey G. Makarov ${ }^{2}$, Olga N. Nizamieva ${ }^{3}$

${ }^{1,2,3}$ Candidate of Juridical Sciences, Department of Civil Law under Kazan (Privolzhsk) Federal University

(Russian Federation, Kazan),

Email: zamira9@yandex.ru; timamakarov@mail.ru; olganizami,eva@mail.ru,Contact: +7917 392 19 51,

\section{Received: 21st October 2017 Accepted: 16th November 2017, Published: 31st December 2017}

\begin{abstract}
The paper outlines some theoretical and methodological issues of researching the rights of ownership of minors: legislative regulation of the norms of civil and family law of Russia, the practice of their application; the unsolved problem of guaranteeing the rights of ownership of minors and their implementation. In particular, in relation to the child's right to receive support, the following problems are considered: the definition of the subject in whose favor a child support is to be collected; determination of the parties to the agreement on payment of alimony; impossibility of realization of a guarantee of interests of a child at the conclusion of an alimony agreement with participation of brothers, sisters, grandmothers and grandfathers, etc.Concerning the right of ownership and other proprietary rights of a child, an assessment is given of their support and implementation characteristics, which is due to the legal nature of the child's rights of ownership; some problems are identified when they are implemented in practice. The authors have come to the conclusion that the solution of the problems mentioned here concerns both the sphere of law making and the sphere of law enforcement. Particular proposals were made to introduce changes and additions to the family, civil, and other sectoral legislation, as well as to improve law enforcement practices.
\end{abstract}

Keywords: Rights of Ownership; Minors; the Right to Support; Right of Ownership of a Child.

\section{Introduction}

The Convention on the Rights of the Child [1] in its Art. 27 provides that participating States recognize the right of every child to a standard of living necessary for the child's physical, mental, spiritual, moral and social development. In fact, we are talking about the welfare of the child, about ensuring his best interests [2, p.36].

The creation of the necessary living conditions for the development of a child is provided mainly by the parents, as well as by other persons raising the child, who are responsible within their abilities and financial possibilities. Russia's participation in the Convention predetermined the consolidation in the national legislation of the complex of rights of minors, including in the property sphere. A number of 2346 measures were taken to raise the living standards of children, to create a comfortable and friendly environment for them, to ensure the legal protection of minors. In the modern world, minors are involved in many property relations. Given the subjective features of rights holders, a system of legal instruments has been created that provide certain guarantees for the exercise by children of their rights. Nevertheless, in some cases, the realization of rights of ownership encounters some difficulties; there are situations when the rights of ownership of minors are violated.This was caused by various circumstances: lack of legal regulation, lack of a unified approach to the realization of the rights of a child, non-application of certain provisions of the law in the field of children's rights, including those born with the help of assisted reproduction [3, p.841-844]. Since the most significant rights of ownership of the child are the right to receive support and right of ownership, in this work attention is focused on the problems of implementation of these rights.

\section{Methods}

In the process of research, a comparative legal method, a right-sociological method, methods of legal modeling and forecasting, and a method of legal interpretation were used.

\section{Results}

Some circumstances that hinder the effective realization of the child's right to receive the supports and exercise his right of ownership are revealed.

\section{Discussion}

The Family Code of the Russian Federation provides for a rule that a child has the right to receive support from his/her parents and other family members. Russian law provides for a system of legal means aimed at the realization of this right, beginning with establishing the variability in the definition of forms, size, methods, order and other parameters for providing support (taking into account the presence or absence of conflict between family members, as well as other 
individual life circumstances) and ending with measures ensuring the receipt of support and establishing liability for improper performance of the duty.In general, it should be recognized that the current Russian legislation regulates in detail the relationship of providing support, but this does not exclude the problem in this area.

Getting by a minor of support from a family member, as a rule, occurs naturally: parents or other persons bear expenses for meeting their needs.It is possible to conclude an agreement on the payment of alimony. However, the highest level of legal guarantees for today has a judicial decision.

A complainant party in the case of alimony recovery for support may be one of the child's parents, the adoptive parent, the guardian (trustee), and the administration of the organization where the child left without parental care is placed, the guardianship and trusteeship body. These persons act on behalf of the child as his/her legal representatives. But the question of who should benefit in alimony (for the benefit of the child or for the benefit of his/her legal representative), who is their recipient, who is the claimant of the alimony in the enforcement proceedings, is resolved ambiguously in practice.

Most often, the court decision states that alimony for the support of a minor is collected in favor of the complainant parent or other legal representative. From this point of view, the recipient of alimony is not the child, but his/her legal representative. The legal representative also acts as a collector in the enforcement proceedings.

At the same time, this approach is fairly criticized. So, in the opinion of A.M. Rabetz, the wording of the court decision on the recovery of alimony in favor of the legal representative, and not in favor of the child, transferred to the writ of execution, may create additional difficulties and conflict situations in the execution of the court decision and endanger the property interests of the child. As far as in such decisions the recipient and the collector alimony is not a child, but his/her legal representative, so far only the latter depends on the actual receipt of alimony by a child.The person in whose favor they are recovered may, in agreement with the payer of alimony at any time, withdraw the executive document.Therefore, the recipient of alimony must be the child himself/herself, and alimony must be collected in his/her favor and for his/her support [4, p.262].

There is the question related to the problem of who acts as a party to the agreement on payment of alimony for the support of a minor: the child himself/herself or his/her legal representative? Art. 99 of the Criminal
Code of the Russian Federation states that the agreement is concluded between the person who is obliged to pay alimony and their beneficiary, and in case of incapacity of the person obliged to pay alimony and (or) the recipient of alimony, between the legal representatives of those persons.From the literal interpretation of the norm, it is possible to conclude: the side of the support agreement is the legal representative of the child. However, the representative acts only on behalf of and in the interests of the represented person, the parties to the agreement are directly the person obliged to pay alimony (the payer) and the person authorized to receive alimony (the recipient).Therefore, the following wording is more correct: "In case of incapacity of a person obliged to pay alimony and (or) a recipient of alimony, an agreement on their behalf is concluded between the legal representatives of those persons" $[5$, p. 357; 6 , p. 88-89; 7, p.193].

Family law grants the parties to the alimony agreement the freedom to determine the amount of alimony, limiting it to the extent that the interests of the child require. According to the par. 2, Art.103 of the Family Code of the Russian Federation the amount of alimony established under the agreement on payment of alimony for minor children cannot be less than the amount of alimony that they could receive in the recovery of alimony in court (Art.81 ofthe Family Code of the Russian Federation). Otherwise, the court may recognize the agreement as null and void (art.102, Family Code of the Russian Federation).

The agreement on payment of alimony can be concluded both with the parent of the child and with other persons obliged to pay alimony: brothers, sisters, grandfathers and grandmothers. At the same time, the determination of the amount of alimony in the share of earnings or other income of an obligated person is used exclusively when collecting alimony from the parents; the Art.81 of the Criminal Code does not apply to the alimony relationships with the participation of other family members. Consequently, as A.Yu. Ilyin correctly notes, "The application of Art.102 of the Criminal Code of the Russian Federation is excluded too", "the guarantees provided for in clause 2 of Article 103 of the Criminal Code of the Russian Federation are applicable only if the agreement on payment of alimony for a minor child is concluded between his/her parents" [8, p.55].

The offender may be subject to liability measures for non-fulfillment or improper performance of alimony obligations, including property sanctions which are differentiated depending on whether alimony is paid by court order or by an alimony agreement. 
Thus, in the event of a debt due to the fault of a person obliged to pay support under a court decision, the guilty person pays a penalty to the recipient of alimony in the amount of $1 / 2 \%$ of the amount of unpaid child support for each day of delay (Section 2, Art.115 of the Family Code of the Russian Federation). In 2008, the penalty was increased by a factor of five, due to the need to increase the responsibility of parents for late payment of alimony and was dictated by the extreme prevalence of cases of evasion from payment of alimony, concealment of income, etc. The Family Code of the Russian Federation does not provide reduction of forfeits, and the inadmissibility of the application of Art.333 of the Civil Code of the Russian Federation, which allows the court to reduce the forfeit, follows from the explanations of the Supreme Court of the Russian Federation [9, 10]. Thus, liability measures applicable to unfair payers of child support are serious enough.

With a view of mitigating the legislative regulation of the question of the amount of the penalty for late payment of support in July 2017, a bill was introduced in the State Duma of the Russian Federation [11], providing for the court's right to reduce the forfeit, taking into account the material and family status of the payer of alimony.In the opinion of the authors of the draft law, the increase in responsibility that took place in 2008 fulfilled its task and affected in general the behavior of the payers of alimony.The absence of a rule allowing the court to reduce the penalty for nonpayment of alimony leads to a penalty of several million rubles, which is practically impossible to pay. As a result, a debtor is in a difficult financial situation and stops paying alimony. Adoption of the bill will allow payers of alimony to pay a proportional penalty, and to receive support for children.

But the proposed changes are premature. The problem of non-payment of alimony for minor children is preserved, the support is often provided irregularly or in insufficient quantity, or a parent refuses to provide support voluntarily at all [10].

The question of responsibility for improper performance of an alimony obligation established by an alimony agreement remains open. When the debt is formed, the guilty person is liable in the manner provided for by such an agreement (Clause 1, Art.115 of theFamily Code of the Russian Federation). The law leaves without attention the cases when the supportagreement does not contain provisions on sanctions, Courts come up in different ways to solving this problem.To date, some courts have exempt payers of alimony from liability, other courts, based on Art.101 of the Family Code of the Russian Federation, apply the rules on civil liability for violation of monetary obligations (collect interest under Art.395 of the Civil Code), the third courts apply the guilty persons by analogy to the measures envisaged for the recovery of alimony in court, that is, the rules of clause 2 of Art.115 from the Criminal Code of the Russian Federation [12].In order to ensure uniformity of judicial practice, we have already suggested a proposal on the expediency of appropriate changes to clause 1, article 115 of the Criminal Code of the Russian Federation and the arguments in favor of establishing uniform measures of responsibility for improper performance of alimony duties, regardless of the reason for their occurrence [13, p.208-209].

The minor child acquires the right of ownership for various amounts due to the, including those received for support [5, p.224-225].

The amounts received are put at the disposal of parents or persons officially substituting them and should be spent exclusively on the support, upbringing and education of the child. In the interests of the child, the court may decide not to transfer more than $50 \%$ of the alimony amount to the account opened in the name of the minor in a bank.

In order to protect the rights of ownership of the child, par. 1, Art. 37 of the Civil Code stipulates that the income of a ward, including those due to him/her from the management of his/her property, with the exception of income that the ward is entitled to dispose of independently, is spent by the guardian or trustee exclusively in the interests of the ward and with the prior permission of the guardianship and trusteeship body.The amounts of alimony, pensions, allowances, compensation for harm to health and harm suffered in the event of loss of the bread-winner, as well as other payments paid for the support of the ward, with the exception of income that the wards are entitled to dispose of independently, are credited to a nominal account opened by the guardian or trustee, and they are spent by them without the prior permission of the guardianship and trusteeship authority, with a subsequent report on the expenditure of such amounts. Procedure for control of the property of the ward is defined by art.19 of the Federal Law "On Guardianship and Trusteeship".

A minor acquires the right to ownership of all the received income (earnings, author's remuneration, interest from a bank deposit, etc.), and property received as a gift or by inheritance, as well as to any other property acquired with the funds of a minor child. A minor may become an owner on other grounds, for example, as a result of privatization of a dwelling. 
Being an owner, a minor has the right to own, use and dispose of his/her property. Legislator does not specifically stipulate the peculiarities of exercising possession and use to minors, and accordingly the latter exercises those powers independently. The limits of the possible realization of the disposal powers are determined by the amount of legal capacity to act of the minor.

Thus, minors under the age of 14 have the right to perform only certain types of transactions themselves, named in art. 28, the Civil Code of the Russian Federation. If a child commits a transaction exceeding the powers granted to him/her by law, the transaction is recognized as null and void.But in the interests of a minor, and at the request of his/her legal representatives, the court may recognize as valid a transaction made to the apparent benefit of the minor (Section 2, Art.172 of the Civil Code of the Russian Federation).

The list of transactions possible for minors between the ages of fourteen and eighteen years old is specified in Art.26 of the Civil Code of the Russian Federation. Such minors commit other transactions exclusively with the written consent of their legal representatives; possibly at the same time and the subsequent written approval of the transaction.

If a transaction is committed by a minor with a violation of these requirements, the court may recognize it as invalid on the basis of a claim by the parents, adoptive parents, or guardian. The only exception is transactions that are performed by minors which had become fully capable to act (Section 2, Art.175, the Civil Code of the Russian Federation).

Family legislation of Russia establishes the principle of separation of parents' and children's property: a child does not have the right to own property of his/her parents, nor does his/her parents have the right to own property of his/her child. A minor's property cannot be also the subject of a marriage contract.

A similar norm is provided for the rights of ownership of the wards: wards do not have the right of ownership to the property of guardians or trustees, and guardians or trustees do not have ownership rights to the property of the wards, including alimony, pensions, allowances and other social payments provided for support (art.17 of the Trusteeship Act).

At the same time, the Family Code of the Russian Federation grants a child the right to own and use the property of his/her parents when living with them. Still D.I. Meyer wrote: "Parents allow children to use their property...; children... consider it a blessing to serve their parents with their property...". [14, p.751] An obligatory condition here is the consent of the legal representatives of the child and the common residence of the child with them.

A similar right exists for minors over which a trusteeship or guardianship has been established. According to paragraph 3, Art. 17 of the Trusteeship Law, wards are entitled to use the property of their guardians or trustees with their consent, while guardians and trustees are not entitled to use the property of the wards for their own benefit, with the exception of cases provided for in Art. 16 of the said law.

Property can be in the common ownership of minors and their parents.In particular, such a right can arise when inheriting property as a result of privatization of a dwelling and in some other cases. The possession, use and disposition of the common property of minors and their parents are subject to the rules of the Civil Code of the Russian Federation.

When dividing the inheritance in order to protect the legitimate interests of minors, the requirements of Art. 1167 of the Civil Code of the Russian Federation should be met: in the case if minor heirs are available, the division of the inheritance must be carried out with the mandatory observance of the rules of Art. 37 of the Civil Code of the Russian Federation; the guardianship and trusteeship authority must be notified on the drawing up of an agreement on the division of the inheritance and on the consideration in the court of the case concerning the division of the inheritance.

It should be noted that other proprietary rights or rights of ownership with real-legal grounds are also possible for minors [15, p.13-14].

A child has a right of ownership to things acquired by his/her parents solely to meet his/her needs.Since such things are purchased, usually with the help of parents, it is logical to assume that it is the parents who become the owners of these things (although it is believed that in essence, a child becomes the owner of these things [16, pp. 308, 17, p.28]).However, things are purchased exclusively to meet the needs of the minor (clothes, shoes, school and sports supplies, musical instruments, children's library, etc.), and therefore in accordance with cl.38 of the Family Code of the Russian Federation they are not subject to division and are transferred without compensation to that of the spouses with whom the child lives. Consequently, it can be assumed that there is a limited right of ownership of the child in relation to the named things. Contributions made by spouses at the expense of their common property and in the name of their common minor children also belong to the children and do not take into account when sharing common property of spouses. 
Thus, depending on the qualification of the minor's right to the things acquired by his/her parents to meet the needs of the child, the appropriate legal regime is determined as to the property and the distribution or non-distribution to the parents of the restrictions provided for in Art.37 of the Civil Code.

A minor has the right to use premises of the living quarters in the capacity of a member of the owner's family (art. 292 of the Civil Code of the Russian Federation).

By a general rule, the transfer of ownership of a residential house or apartment to another person is the basis for the termination of the right to use a dwelling by members of the family of the previous owner, unless otherwise provided by law. However, if the family members of the owner of the given dwelling or those who are left without parental care are living in the dwelling place, the minor members of the owner's family (as is known to the guardianship authority) and if the rights or interests of the said persons protected by law are affected, alienation of such premises is possible only with the consent of the guardianship and trusteeship authority (clause 4, art.292 of the Civil Code of the Russian Federation). It should be noted that the Constitutional Court of the Russian Federation recognized this point as not in accordance with the Constitution of the Russian Federation in the part determining the order of alienation of a dwelling in which minors of the family of the owner of a dwelling are residing, if their rights or interests protected by law are affected [18].

\section{Summary}

In our opinion, the solution of the problems outlined in the work, which impede the effective realization of the rights of ownership of minors, has two perspectives: law-making and law enforcement. Some of the issues can be resolved by improving the law enforcement practice, including at the level of the Supreme Court of the Russian Federation. To solve other problems, it will be necessary to introduce changes and additions to the family, civil and other sectoral legislation.

\section{Conclusion}

The right to receive support and the right to ownership are the most important proprietary rights of a minor, which need not only proper legislative regulation, but also proper provision of their implementation in practice.

\section{Acknowledgement}

The work is performed according to the Russian Government Program of Competitive Growth of Kazan Federal University.

\section{References}

[1] Convention on the Rights of the Child (New York, 20.11.1989)

http://www.un.org/en/documents/decl_conv/conventio ns/childcon.shtml. See: Implementation handbook for the convention on the rights of the child / prep. for UNICEF by Rachel Hodgkin and Peter Newell (fully revised third edition). New York: UNICEF, 2007. 787 p.; Revisiting children's rights: 10 years of the UN Convention on the Rights of the Child / edited by Deirdre Fottrell. The Hague: Kluwer Law International, 2000. 196 p.; The standard of the best interests of the child: a western tradition in international and comparative law / by Claire Breen. The Hague: M. Nijhoff, 2002. 321 p.

[2] Boele-Woelki K., Ferrand F., Beilfuss K.G., Jantera-Jareborg M., Lowe N., Martiny D., Pintens W. Principles of European Family Law Regarding Parental Responsibilities. Antwerpen-Oxford: Intersentia, 2007.

[3] Arslanov K., Nizamieva O. Surrogacy: Legal and Moral Dimension of the Problem from the Perspective of Russian, Foreign and International Experience // Research Journal of Applied Sciences. 2015. 10 (12). P.841-844.

[4] Commentary on the Family Code of the Russian Federation / Executive editor A.M. Nechaeva. Moscow, 2008. $548 \mathrm{p}$.

[5] Commentary on the Family Code of the Russian Federation (article-for-article) / Executive editor O.N. Nizamieva. Moscow, 2010. 560 p.

[6] Ksenofontova D.S. Legal guarantees in the field of alimentation: a thesis for the degree of Candidate of Juridical Sciences.Kazan, 2015. 229 p.

[7] Family law: a textbook / ed. by P.V. Krasheninnikov. Moscow, 2010. 300 p.

[8] IlyinaO.Yu. A New Perspective on the Alimony Commitment on the Support of Children // Socio-legal notebook.2016. Release 6. P.47-57.

[9] Review of the judicial practice of the Supreme Court of the Russian Federation for the third quarter of 2012, approved by the Presidium of the Supreme Court of the Russian Federation on 26.12. 2012.// Bulletin of the Supreme Court of the Russian Federation. 2013.№4.

[10] Review of judicial practice in cases involving the collection of alimony for minor children, as well as for disabled adult children; approved by the Presidium of the Supreme Court of the Russian Federation on May 
13, 2015.URL:

http://www.supcourt.ru/Show_pdf.php?Id=10042.

[11] Bill No. 220429-7 "On Amending Article 115 of the Family Code of the Russian Federation". URL: http://asozd2.duma.gov.ru/main.nsf/(Spravka)?OpenAg ent $\& R N=220429-7$.

[12] The definition of the Constitutional Court of the Russian Federation dd. 23.06. 2015.№1452-O "On refusal to accept for consideration the complaint of the citizen Shuklina E.S. on violation of her constitutional rights by Article 115 of the Criminal Code of the Russian Federation".URL: http://doc.ksrf.ru/decision/KSRFDecision202831.pdf;

Review of the judicial practice of the Chelyabinsk Regional Court for the fourth quarter of 2014, approved by the Presidium of the Chelyabinsk Regional Court of 25.02.2015. Resolution No. 44g73/2014.URL: $\quad$ http://www.cheloblsud.ru/upload/file/reviews/general/reviews_2014_0 4.pdf.

[13] Nizamieva O.N. Actual issues of judicial practice in the application of measures of responsibility for improper performance of alimony duties // Proceedingsof Kazan university. Series"Humanitarian sciences". 2015. V.157, Book6. P.204-211.

[14] Meyer, D.I. Russian Civil Law (in 2 parts). M., 2003. $831 \mathrm{p}$.

[15] Akhmet'yanova Z.A. On the question of the real rights of minors // Bulletin of the Tver State University.2014. № 2. Pp. 13-22.

[16] Civil law: a textbook. In 3 parts.P. 3 / Ed.by A.P.Sergeev, Yu.K. Tolstoy.Moscow, 1998. 592 p.

[17] Sorokin S. Rights of ownership of a child in the family // Russian Justice.2000. № 2. Pp. 28-29.

[18] Decree of the Constitutional Court of the Russian Federation dated 08.06. 2010No. 13-P "On the case on verification of the constitutionality of paragraph 4 , Article 292, the Civil Code of the Russian Federation in connection with the complaint of the citizen V.V. Chaadayeva"// RossiyskayaGazeta.2010. 17th of June. 